\title{
Article \\ Comparative Effects of Bio-Wastes in Combination with Plant Growth-Promoting Bacteria on Growth and Productivity of Okra
}

\author{
Hammad Anwar ${ }^{1}$, Xiukang Wang ${ }^{2, *}$, Azhar Hussain ${ }^{1, *}$, Muhammad Rafay ${ }^{3}$, Maqshoof Ahmad ${ }^{1}$ (D), \\ Muhammad Latif ${ }^{4}$, Muhammad Usman Jamshaid ${ }^{5}$, Imran Khalid ${ }^{6}$, Abubakar Dar ${ }^{1}$ and Adnan Mustafa ${ }^{7}$ (D)
}

Citation: Anwar, H.; Wang, X.; Hussain, A.; Rafay, M.; Ahmad, M.; Latif, M.; Jamshaid, M.U.; Khalid, I.; Dar, A.; Mustafa, A. Comparative Effects of Bio-Wastes in Combination with Plant Growth-Promoting Bacteria on Growth and Productivity of Okra. Agronomy 2021, 11, 2065. https://doi.org/10.3390/agronomy 11102065

Academic Editors: Mumtaz Cheema and Muhammad Nadeem

Received: 9 September 2021

Accepted: 11 October 2021

Published: 14 October 2021

Publisher's Note: MDPI stays neutral with regard to jurisdictional claims in published maps and institutional affiliations.

Copyright: (c) 2021 by the authors. Licensee MDPI, Basel, Switzerland. This article is an open access article distributed under the terms and conditions of the Creative Commons Attribution (CC BY) license (https:/ / creativecommons.org/licenses/by/ $4.0 /)$.
1 Department of Soil Science, The Islamia University of Bahawalpur, Bahawalpur 63100, Pakistan; hammadanwar7278@gmail.com (H.A.); maqshoof_ahmad@yahoo.com (M.A.); abubakardar3206@gmail.com (A.D.)

2 College of Life Sciences, Yan'an University, Yan'an 716000, China

3 Department of Forestry Range and Wildlife Management, The Islamia University of Bahawalpur, Bahawalpur 63100, Pakistan; rafay@iub.edu.pk

4 Department of Agronomy, The Islamia University of Bahawalpur, Bahawalpur 63100, Pakistan; mlatifiub@gmail.com

5 Department of Soil \& Environment, Muhammad Nawaz Shareef University of Agriculture, Multan 59220, Pakistan; usman.jamshaid@mnsuam.edu.pk

6 Department of Agriculture Extension, The Islamia University of Bahawalpur, Bahawalpur 63100, Pakistan; imrankhalid@iub.edu.pk

7 Biology Centre CAS, SoWa RI, Na Sádkách 7, 37005 Cěské Budějovice, Czech Republic; adnanmustafa780@gmail.com

* Correspondence: wangxiukang@yau.edu.cn (X.W.); azharhaseen@gmail.com (A.H.)

\begin{abstract}
Plant growth-promoting rhizobacteria with multiple growth-promoting traits play a significant role in soil to improve soil health, crop growth and yield. Recent research studies have focused on the integration of organic amendments with plant growth-promoting rhizobacteria (PGPR) to enhance soil fertility and reduce the hazardous effects of chemical fertilizers. This study aims to evaluate the integrated application of biochar, compost, fruit and vegetable waste, and Bacillus subtilis (SMBL 1) to soil in sole application and in combined form. The study comprises eight treatmentsfour treatments without inoculation and four treatments with SMBL 1 inoculation in a completely randomized design (CRD), under factorial settings with four replications. The results indicate that the integrated treatments significantly improved okra growth and yield compared with sole applications. The integration of SMBL 1 with biochar showed significant improvements in plant height, root length, leaf chlorophyll a and b, leaf relative water content, fruit weight, diameter and length by 29, 29, 50, $53.3,4.3,44.7$ and $40.4 \%$, respectively, compared with control. Similarly, fruit N, P and K contents were improved by $33,52.7$ and $25.6 \%$ and $\mathrm{Fe}$ and $\mathrm{Zn}$ in shoot were 37.1 and $35.6 \%$, respectively, compared with control. The results of this study reveal that the integration of SMBL 1 with organic amendments is an effective approach to the sustainable production of okra.
\end{abstract}

Keywords: Bacillus subtilis; biochar; compost; okra; organic amendments; sustainable

\section{Introduction}

Okra (Abelmoschus esculentus L.) belongs to the Malvaceae family and is one of the most famous vegetables. The main purpose of this crop is to consume its immature pods as boiled and fried vegetable or add them to soups, stews or salads [1]. Okra is extensively used as vegetable crop and provides important nutritional contents for the human diet, such as minerals, proteins, carbohydrates and vitamins [2]. Young okra pods contain $0.2 \%$ fat, $2.2 \%$ protein, $86 \%$ water, $10 \%$ carbohydrates and vitamins A, B, C [3]. During 2019 , 121.5 thousand tons of okra were produced from an area of 15.7 thousand hectares with a major contribution of Punjab (68.8 thousand tons), followed by Sindh (20.3 thousand tones), 
Khyber Pakhtunkhwa (17.7 thousand tons) and Baluchistan (14.8 million tons), showing a decrease compared with previous years due to harsh environmental conditions [4].

Climate change, harsh environmental conditions and other abiotic factors are responsible for lowering crop yields in arid and semiarid regions. Furthermore, extensive cultivation of and agricultural production obtained from the same piece of land are responsible for nutrient imbalance, decreased soil fertility, loss of biodiversity and expedite organic matter decomposition. Due to these reasons, okra yields are gradually declining not only in Pakistan but in all the developing countries. High cropping intensity and leaching, soil particle fixation and surface runoff are the major causes for the loss of nitrogen and other nutrients [5]. Excessive use of agrochemicals (fertilizers and pesticides) after the green revolution has posed negative effects on the environment, such as greenhouse gas emissions, nutrients leaching, increase in agrochemical residues in food and salinization of agricultural soils [6]. Tillage operations have expedited the organic matter decomposition in cultivated lands and have altered the $\mathrm{pH}$, provoking a shift towards alkalinity, which is responsible for the depletion of the soil nutrient pool. Furthermore, the slow release of nutrients by organic amendments has caused a reduction in the application of organic amendments, which further deteriorated the soil conditions [7]. Soil organic carbon (SOC) performs a vital role in the development of soil biological and physiochemical characteristics for crop yield improvement via increasing the water holding capacity, carbon sequestering, reduced nutrient leaching, soil erosion, improved nutrient cycling and gaseous exchange in soil [8]. The use of organic amendments/biofertilizers of plant and animal origin increases soil organic carbon [9]. As organic matter is a key factor for controlling soil properties and enhancing crop yield, Ramesh [10] demonstrated that the application of microbes and organic amendments is the only method to improve organic carbon contents in soil. Organic farming, such as the repeated application of beneficial microbes and organic amendments, is gaining importance day by day in relation to enhancing microbial diversity and sustainable production of crops [11].

Biochar, an organic amendment, is a pyrolysis product of plant waste [12] and has ability to influence/improve chemical, physical and biological attributes of soil, making it favorable for crop production $[13,14]$. The application of biochar has proved to be a sustainable approach as it improves the yield, growth and quality of fruit, as well as their nutrient status and the water use efficiency of crops (WUE) [15]. Moreover, the improvement in soil chemical properties (cation exchange capacity (CEC), exchangeable sodium percentage (ESP) and soil $\mathrm{pH}$ ) through biochar application under salt stress was found responsible for improving the nutritional status of sunflower [5]. Sänger et al. [16] suggested that the biochar application alone and in combination with other organic amendments, biofertilizers or mineral fertilizers to marginal lands provides sustainable crop production by not only improving physical (water holding capacity and high surface area) and chemical attributes (high CEC) of soil [17], but also enhancing its biological parameters, such as microbial populations and their activities [18-20]. Similarly, compost is also beneficial for improving plant growth by enhancing the water-holding capacity and organic carbon in soil [21]. The use of compost in soil conserves the environmental quality as a sustainable agriculture practice [22]. Compost is also an important organic amendment that can be applied to lessen the chemical fertilizers requirements, promote water-holding capacity, microbial enzyme activities and biological populations not only under normal soil conditions but also under stress environments $[23,24]$.

The microorganisms present in soil are the main source of nutrient recycling, such as fixation of nitrogen $(\mathrm{N})$ and mineralization of SOC; in this way, they improve nutrient sustainability [25]. These microbes secrete different kinds of extracellular enzymes to capture carbon and other nutrients, converting complex molecules into simpler forms by degradation depending on the abundance and microbial diversity [26]. Therefore, plant growth-promoting rhizobacteria (PGPR) can improve the growth of plants by defending plants from stress conditions and soil-borne diseases and enhance plant growth via synthesizing extracellular enzymes and phytohormones, as well as promoting antifungal activity, 
nitrogen fixation, nutrient availability, improving ACC-deaminase activity and phosphorus, potassium and zinc solubilization [27-29]. Hales and his coworkers [30] used biochar as a an alternate PGPR carrier instead of peat and vermiculite and found promising results. Nadeem et al. [31] found increased growth and physiological attributes of cucumber and soil biological parameters $(\mathrm{CFU}=$ colony forming unit) through the synergistic use of $\mathrm{Pseu}$ domonas fluorescens, compost and biochar under water deficit conditions. Thus, in view of the above situation, this research work was conducted to assess the effects of the combined use of biochar, fruit and vegetable waste, and compost with the Bacillus subtilis SMBL 1 strain on the growth and yield of okra and soil microbial population. The hazardous impact of chemical fertilizers on the environment through conventional applications has posed serious threats to crop production [6] which needs to alter with sustainable approaches to enhance nutrient fortification in crops, especially vegetables.

\section{Materials and Methods}

\subsection{Collection of Biochar, Fruit and Vegetable Waste, and Compost}

Compost made of wheat straw and farmyard manure as raw material and biochar derived from wheat straw were taken from Environmental Microbiology Laboratory, Institute of Soil and Environmental Sciences, University of Agriculture Faisalabad Pakistan. Fruit and vegetable wastes were collected from the local fruit and vegetable market of Bahawalpur, air dried in shade and then ground into powder with the help of a grinder.

\subsection{Identification through $16 S$ rRNA Gene Sequencing of Bacterial Strain (SMBL 1)}

The pre-isolated $\mathrm{P}$ and $\mathrm{Zn}$ solubilizer, IAA producer and ACC-deaminase-producing strain (SMBL 1) was obtained from the Soil Microbiology and Biotechnology Laboratory, Department of Soil Science, The Islamia University of Bahawalpur. The identification of strain SMBL 1 was performed through partial gene sequences of $16 \mathrm{~S}$ rRNA. Initially, DNA extraction was carried out from a SMBL 1 strain cell culture using an extraction buffer containing proteinase K [32]. DNA extraction was followed by a PCR reaction to amplify the $16 \mathrm{~S}$ rRNA sequence using the $27 \mathrm{~F}$ and $1492 \mathrm{R}$ universal primer pair. The reaction mixture contained $3.7 \mu \mathrm{L}$ of crude DNA, $3 \mu \mathrm{L}$ of $27 \mathrm{~F}(10 \mu \mathrm{M}), 3 \mu \mathrm{L}$ of $1492 \mathrm{R}(10 \mu \mathrm{M})$ and $7.5 \mu \mathrm{L}$ of $\mathrm{H}_{2} \mathrm{O}$. The conditions for thermal cycling were $95^{\circ} \mathrm{C}, 1$ cycle for $1 \mathrm{~min}$, followed by 32 amplification cycles of $1 \mathrm{~min}$ at $94{ }^{\circ} \mathrm{C}$ and $20 \mathrm{~s}$ cycle of $55^{\circ} \mathrm{C}$ hold. The PCR products (3 replicates) were sent to the commercial sequencing service Macrogen ${ }^{\circledR}$ Seoul, Korea for $16 \mathrm{~S}$ rRNA sequencing. The obtained sequences of nucleotide were BLAST-compared with the available genome database of NCBI and identified as Bacillus subtilis. Following the Thompson et al. [33] method, a phylogenetic tree was constructed on the MEGA-X software (Figure 1). The processing of data was carried out by using an NJ Plot according to the neighbor joining method [34]. The partial sequence of nucleotides was submitted to the Gen Bank database of NCBI under the accession number of the (SMBL 1) strain, which was MN007187. 


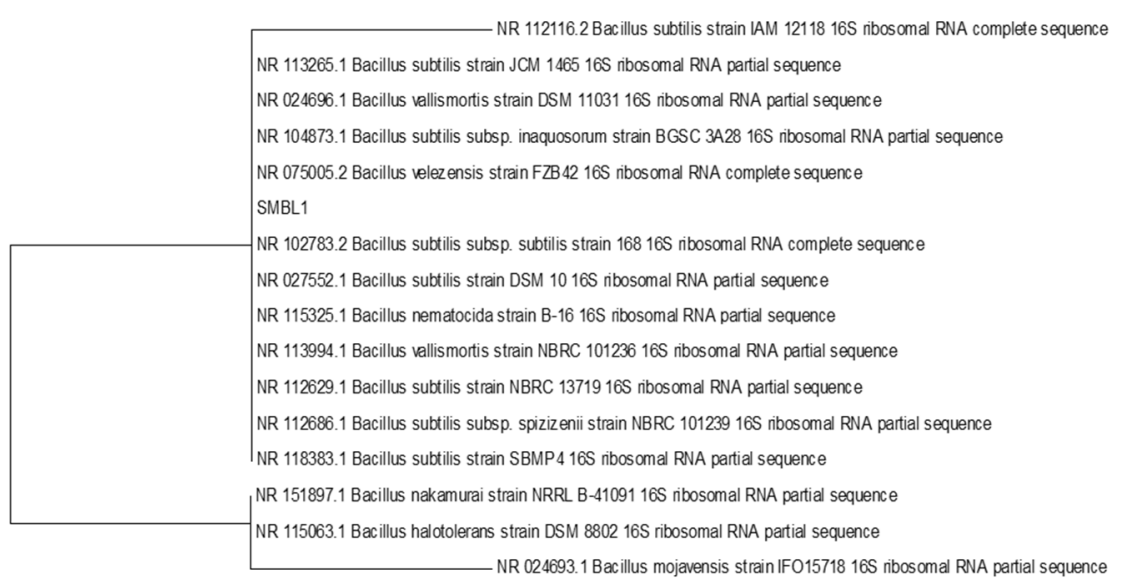

\subsection{0}

Figure 1. Phylogenetic tree of the bacterial strain Bacillus subtilis (SMBL 1) (accession \#MN007187).

\subsection{Analysis of Biochar, Compost, and Fruit and Vegetable Waste}

The chemical analyses of biochar, compost and fruit and vegetable waste were performed at the Department of Soil Science, Soil Microbiology and Biotechnology Lab, Faculty of Agriculture and Environment, The Islamia University of Bahawalpur Pakistan, following the standard method [35]. The electrical conductivity and the $\mathrm{pH}$ of fruit and vegetable waste, compost and biochar with a mass to volume ratio of 1:20 in distilled or deionized water were calculated with an EC- and a pH-meter, respectively. With the help of the method found in [36], the C contents were measured in fruit and vegetable waste, biochar and compost. A Kjeldahl digestion and distillation apparatus was used to determine $\mathrm{N}$ contents [37]. For potassium and phosphorus determination, fruit and vegetable waste, compost and biochar samples were digested through $\mathrm{H}_{2} \mathrm{SO}_{4}$ (sulfuric acid) and $\mathrm{H}_{2} \mathrm{O}_{2}$ (hydrogen peroxide) [38]. A flame photometer was used to determine potassium contents in a digested sample (Model BWB-XP, BWP Technologies, UK). Phosphorus determination in a digested filtrate was performed by a color development in the spectrophotometer (Model G6860A, Cary 60 UV-Vis Agilent Technologies, Australia). The observed chemical characteristics of biochar, compost, and fruit and vegetable waste are given in (Table 1).

Table 1. Physical-chemical parameters of organic amendments and soil used for pot trial.

\begin{tabular}{ccc}
\hline Characteristics & Unit & Values \\
\hline EC & Biochar & \\
pH & $\left(\mathrm{dS} \mathrm{m}^{-1}\right)$ & $1.69 \pm 0.0053$ \\
Nitrogen & - & $7.8 \pm 0.017$ \\
Phosphorus & $\%$ & $0.20 \pm 0.0039$ \\
Potassium & $\%$ & $0.31 \pm 0.0053$ \\
Carbon & $\%$ & $1.98 \pm 0.0053$ \\
& $\%$ & $36.07 \pm 0.048$ \\
\hline Organic matter & Compost & \\
pH & $\%$ & $45.25 \pm 0.39$ \\
Carbon & - & $6.55 \pm 0.035$ \\
Nitrogen & $\%$ & $26.77 \pm 0.22$ \\
Potassium & $\%$ & $1.13 \pm 0.013$ \\
Phosphorus & $\%$ & $1.02 \pm 0.0085$ \\
\hline
\end{tabular}


Table 1. Cont.

\begin{tabular}{ccc}
\hline Characteristics & Unit & Values \\
\hline & Fruit and vegetable waste & \\
\hline Organic matter & $\%$ & $46.5 \pm 0.24$ \\
pH & - & $6.8 \pm 0.013$ \\
Carbon & $\%$ & $27 \pm 0.068$ \\
Nitrogen & $\%$ & $1.15 \pm 0.003$ \\
Potassium & $\%$ & $1.035 \pm 0.005$ \\
Phosphorus & $\%$ & $1.95 \pm 0.053$ \\
\hline & Soil & \\
Clay & $\%$ & $15.4 \pm 0.045$ \\
Silt & $\%$ & $38.5 \pm 0.026$ \\
Sand & $\%$ & $46.1 \pm 0.057$ \\
Textural Class & - & Sandy Loam \\
EC & $\left(\mathrm{dS} \mathrm{m}^{-1}\right)$ & $1.4 \pm 0.027$ \\
pH & - & $8.1 \pm 0.030$ \\
s & $\%$ & $40 \pm 0.45$ \\
Saturation percentage & $\mathrm{mg} \mathrm{kg}^{-1}$ & $5.4 \pm 0.018$ \\
Phosphorus & $\mathrm{mg} \mathrm{kg}^{-1}$ & $145 \pm 0.26$ \\
Potassium & $\%$ & $0.021 \pm 0.0006$ \\
Nitrogen & $\%$ & $0.58 \pm 0.0030$ \\
\hline Organic matter &
\end{tabular}

Values are means of four replications \pm standard error.

\subsection{Inoculation of Seed and Management of Experiment}

Okra seeds were purchased from a local market (variety: Pusa Sawani) and sterilized by dipping for $2 \mathrm{~min}$ in ethanol (95\%) followed by $\mathrm{HgCl}_{2}(0.2 \%)$ for 4 minutes then washed with autoclaved distilled water for 5-6 times. Afterwards, the seeds were soaked in a $48 \mathrm{~h}$ old broth culture of the SMBL 1 strain for $30 \mathrm{~min}$ prior to sowing for inoculated treatments, while the seeds of un-inoculated treatments were dipped in a sterilized growth medium (Luria-Bertani or LB medium) [39-41]. The treatment of this study comprised two sets, i.e., the un-inoculated set $(\mathrm{T} 0=$ control, $\mathrm{T} 1=$ compost, $\mathrm{T} 2=$ biochar and $\mathrm{T} 3=$ fruit and vegetable waste) and the inoculated set (T0 = SMBL 1, T1 = compost + SMBL 1, T2 = biochar + SMBL 1 and T3 = fruit and vegetable waste + SMBL 1), replicated thrice.

The pot experiment was carried out in the wire house of the Department of Soil Science, Faculty of Agriculture and Environment of Islamia University of Bahawalpur, Pakistan. Soil physical-chemical characteristics were examined prior to use in the experiment (Table 1). Each pot (length, 18 inch; width, 12 inch) was filled with approximately $10 \mathrm{~kg}$ of air dried, clean (free from leaves, stems and stones) and sieved soil. Un-inoculated and inoculated seeds (10 seeds per pot) were sown in different pots and a homogeneous plant population (3 plants per pot) were maintained after germination. Organic amendments with biochar ( $0.25 \%$ ratio), compost $\left(600 \mathrm{~kg} \mathrm{ha}^{-1}\right)$, fruit and vegetable waste $\left(600 \mathrm{~kg} \mathrm{ha}^{-1}\right)$ and, N:P:K recommended doses (150:112:75 $\mathrm{kg} \mathrm{ha}^{-1}$ ) were applied as urea, DAP (di-ammonium phosphate) and MOP (muriate of potash). Recommended agronomic practices (thinning, irrigation, fertilizer application and weeding) were adopted where and when needed. DAP and MOP were applied at sowing time, while the application of urea was performed in three splits; the 1st dose was applied at sowing time and the remaining splits were applied after a fifteen-day interval. Good quality water fulfilling the fitness criteria as purposed by Ayers and Westcot [42] was used to irrigate the pots. Data regarding physiological attributes were recorded at physiological maturity while the data about growth factors (weight and length of root and shoot) and parameters of yield were noted at harvest.

\subsection{Plant and Fruit Analysis}

After 60 days of germination, okra leaves samples were taken and evaluated for RWC (relative water contents) by using the formula proposed by Mayak et al. [43]. A 
spectrophotometer was used for chlorophyll ' $a$ ' and ' $b$ ' contents and their values were calculated by following method as described by Arnon [44].

At the time of fruit maturity, fruits were harvested and parameters such as number of fruits per plant, fruit fresh and dry biomass and fruit average diameter were recorded. The shoot and fruit samples from each pot were oven dried and ground separately. Samples were digested using the wet digestion procedure as proposed by Wolf [45]. Nutrient concentration in okra shoots and fruit samples were determined using four replicates of each treatment. The Kjeldhal method was used for nitrogen determination in shoot and fruit samples [35]. Phosphorus was measured by the vanadomolybdophosphoric acid yellow color method [37], while the potassium (K) in shoot and fruit samples was measured with a flame photometer [35]. Digested plant samples were examined for $\mathrm{Zn}$ and Fe contents using atomic absorption spectrophotometry (Model 240FS AA, Agilent Technologies Australia, Mulgrave, VIC, Australia).

\subsection{Bacterial Population}

Soil samples were collected after okra harvesting and stored at $4{ }^{\circ} \mathrm{C}$ in a polythene bag until analyzed for CFU. The serial dilution plate technique was used to find the CFU in soil as described by Alexander [46].

\subsection{Statistical Analysis}

An analysis of variance (ANOVA) was used to assess the data by the use of a factorial design (up to two-way interaction); we compared the means by LSD (least significant difference) tests at a probability level of 5\% [47].

\section{Results}

\subsection{Growth Parameters}

The results revealed that the application of Bacillus subtilis (SMBL 1) with biochar, fruit and vegetable waste, and compost promoted plant height, as well as shoot fresh and dry biomass, while sole biochar, fruit and vegetable waste, and compost application also showed prominent results as compared to control (Table 2). However, root length and root fresh and dry biomass of okra was only improved when these organic amendments were applied with SMBL 1 (Table 3). Notably, the highest increase in plant height, root length and biomass were recorded in the biochar + SMBL 1 treatment.

Table 2. Effect of compost, biochar, fruit and vegetable waste (F and V waste) and Bacillus subtilis SMBL 1 on plant height and shoot fresh and dry biomass of okra.

\begin{tabular}{|c|c|c|c|c|c|c|}
\hline \multirow{2}{*}{ Treatments } & \multicolumn{2}{|c|}{ Plant Height (cm) } & \multicolumn{2}{|c|}{$\begin{array}{l}\text { Shoot Fresh Biomass } \\
\left(\mathrm{g} \text { plant }^{-1}\right)\end{array}$} & \multicolumn{2}{|c|}{$\begin{array}{l}\text { Shoot Dry Biomass } \\
\left(\text { g plant }^{-1}\right)\end{array}$} \\
\hline & Un-Inoculated & Inoculated & Un-Inoculated & Inoculated & Un-Inoculated & Inoculated \\
\hline Control & $53.9 \mathrm{~h}$ & $60.4 \mathrm{f}$ & $131.3 \mathrm{~g}$ & $140.5 \mathrm{e}$ & $57.1 \mathrm{~g}$ & $60.9 \mathrm{f}$ \\
\hline Compost & $57.3 \mathrm{~g}$ & $66.5 \mathrm{~d}$ & $136.8 \mathrm{f}$ & $146.8 \mathrm{~cd}$ & $63.6 \mathrm{e}$ & $67.8 \mathrm{~cd}$ \\
\hline Biochar & $70.0 \mathrm{c}$ & $77.9 \mathrm{a}$ & $148.0 \mathrm{c}$ & $156.0 \mathrm{a}$ & $69.9 c$ & $75.8 \mathrm{a}$ \\
\hline $\mathrm{F}$ and $\mathrm{V}$ waste & $63.1 \mathrm{e}$ & $72.9 \mathrm{~b}$ & $143.8 \mathrm{~d}$ & $151.5 \mathrm{~b}$ & $67.0 \mathrm{~d}$ & $72.6 \mathrm{~b}$ \\
\hline $\operatorname{LSD}(p \leq 0.05)$ & \multicolumn{2}{|c|}{2.1113} & \multicolumn{2}{|c|}{3.1584} & \multicolumn{2}{|c|}{2.3259} \\
\hline
\end{tabular}

Means sharing different letters are statistically significant in respect to each other at a $5 \%$ level of probability $(n=4)$. 
Table 3. Effect of compost, biochar, fruit and vegetable waste (F and V waste) and Bacillus subtilis SMBL 1 on root length, and root fresh and dry biomass of okra.

\begin{tabular}{ccccccc}
\hline \multirow{2}{*}{ Treatments } & \multicolumn{2}{c}{ Root Length $\mathbf{( c m )}$} & \multicolumn{2}{c}{ Root Fresh Biomass (g plant $\left.^{-1}\right)$} & \multicolumn{2}{c}{ Root Dry Biomass (g plant $\left.^{-1}\right)$} \\
\cline { 2 - 7 } & Un-Inoculated & Inoculated & Un-Inoculated & Inoculated & Un-Inoculated & Inoculated \\
\hline Control & $15.4 \mathrm{~g}$ & $17.8 \mathrm{ef}$ & $54.3 \mathrm{~g}$ & $57.8 \mathrm{f}$ & $20.9 \mathrm{~g}$ & $24.5 \mathrm{de}$ \\
Compost & $16.9 \mathrm{f}$ & $20.6 \mathrm{c}$ & $61.0 \mathrm{ef}$ & $65.5 \mathrm{~cd}$ & $22.0 \mathrm{fg}$ & $25.8 \mathrm{~cd}$ \\
Biochar & $19 \mathrm{~d}$ & $23 \mathrm{a}$ & $67.0 \mathrm{bc}$ & $74.8 \mathrm{a}$ & $27.0 \mathrm{bc}$ & $31.5 \mathrm{a}$ \\
F and V waste & $18.1 \mathrm{e}$ & $22 \mathrm{~b}$ & $63.5 \mathrm{de}$ & $70.0 \mathrm{~b}$ & $23.1 \mathrm{ef}$ & $28.8 \mathrm{~b}$ \\
\hline LSD $(p \leq 0.05)$ & & 0.8589 & \multicolumn{3}{c}{3.3449} \\
\hline
\end{tabular}

Means sharing different letters are statistically significant in respect to each other at a $5 \%$ level of probability $(n=4)$.

\subsection{N, P, K Contents in Shoot and Fruit}

Inoculation of seed with SMBL 1 and soil amended with organic amendments (biochar, fruit and vegetable waste, and compost) showed significant increase in NPK concentration in okra shoot and fruit over control (Tables 4 and 5). Integrated use of SMBL 1 with biochar improves the $\mathrm{N}$ contents up to $21.3 \%$, P contents up to $41.8 \%$ and $\mathrm{K}$ contents up to $26 \%$ in okra shoot, while NPK in fruit increased up to $33 \%, 52.7 \%$ and $25.6 \%$, compared with control. Fruit and vegetable waste and compost also increased the NPK concentration in shoot and fruit. In the sole application of organic amendments, biochar also showed better NPK concentration in shoot up to $16.9 \%, 37.8 \%$ and $17.6 \%$, respectively, while in fruit $\mathrm{N}$ improved by $24 \%$, P improved by $33.7 \%$ and $\mathrm{K}$ improved by $28.4 \%$ compared with control.

Table 4. Effect of compost, biochar, fruit and vegetable waste (F and V waste) and Bacillus subtilis SMBL 1 on N, P, K in shoot of okra.

\begin{tabular}{ccccccc}
\hline \multirow{2}{*}{ Treatments } & \multicolumn{2}{c}{ Nitrogen in Shoot \% } & \multicolumn{2}{c}{ Phosphorus in Shoot $\%$} & \multicolumn{2}{c}{ Potassium in Shoot \% } \\
\cline { 2 - 7 } & Un-Inoculated & Inoculated & Un-Inoculated & Inoculated & Un-Inoculated & Inoculated \\
\hline Control & $1.93 \mathrm{f}$ & $2.35 \mathrm{~cd}$ & $0.25 \mathrm{f}$ & $0.31 \mathrm{~d}$ & $1.28 \mathrm{f}$ & $1.64 \mathrm{~cd}$ \\
Compost & $2.08 \mathrm{ef}$ & $2.58 \mathrm{bc}$ & $0.27 \mathrm{ef}$ & $0.36 \mathrm{c}$ & $1.38 \mathrm{ef}$ & $1.80 \mathrm{bc}$ \\
Biochar & $2.25 \mathrm{de}$ & $2.85 \mathrm{a}$ & $0.34 \mathrm{c}$ & $0.43 \mathrm{a}$ & $1.50 \mathrm{de}$ & $2.06 \mathrm{a}$ \\
F and V waste & $2.18 \mathrm{de}$ & $2.65 \mathrm{ab}$ & $0.30 \mathrm{de}$ & $0.39 \mathrm{~b}$ & $1.43 \mathrm{ef}$ & 0.1867 \\
\hline LSD $(p \leq 0.05)$ & & \multicolumn{3}{c}{0.0310} \\
\hline
\end{tabular}

Means sharing different letters are statistically significant in respect to each other at $5 \%$ level of probability $(n=4)$.

Table 5. Effect of compost, biochar, fruit and vegetable waste (F and V waste) and Bacillus subtilis SMBL 1 on N, P, K in fruit of okra.

\begin{tabular}{ccccccc}
\hline \multirow{2}{*}{ Treatments } & \multicolumn{2}{c}{ Nitrogen in Fruit \% } & \multicolumn{2}{c}{ Phosphorus in Fruit \% } & \multicolumn{2}{c}{ Potassium in Fruit \% } \\
\cline { 2 - 7 } & Un-Inoculated & Inoculated & Un-Inoculated & Inoculated & Un-Inoculated & Inoculated \\
\hline Control & $1.88 \mathrm{f}$ & $2.35 \mathrm{~cd}$ & $0.25 \mathrm{f}$ & $0.28 \mathrm{def}$ & $1.28 \mathrm{f}$ & $1.56 \mathrm{~cd}$ \\
Compost & $2.08 \mathrm{ef}$ & $2.58 \mathrm{bc}$ & $0.27 \mathrm{ef}$ & $0.33 \mathrm{~cd}$ & $1.38 \mathrm{ef}$ & $1.80 \mathrm{~b}$ \\
Biochar & $2.33 \mathrm{~d}$ & $3.13 \mathrm{a}$ & $0.33 \mathrm{bc}$ & $0.43 \mathrm{a}$ & $1.64 \mathrm{c}$ & $1.96 \mathrm{a}$ \\
F and V waste & $2.20 \mathrm{de}$ & $2.80 \mathrm{~b}$ & $0.30 \mathrm{cde}$ & $0.37 \mathrm{~b}$ & $1.43 \mathrm{de}$ & $1.86 \mathrm{ab}$ \\
\hline LSD $(p \leq 0.05)$ & & & \multicolumn{2}{c}{0.0461} & & 0.1383 \\
\hline
\end{tabular}

Means sharing different letters are statistically significant in respect to each other at $5 \%$ level of probability $(n=4)$.

\subsection{Yield Parameters}

In the yield-contributing parameters of okra, the numbers of fruit plant ${ }^{-1}$ were promoted significantly by the application of the SMBL 1 strain with biochar, fruit and vegetable waste, and compost (Table 6). The highest number of fruit plant ${ }^{-1}(18.0)$ was obtained by the application of biochar + SMBL 1, followed by fruit and vegetable waste + SMBL 1 
(16.0) and compost + SMBL 1 (11.0). While, in sole application of organic amendments, the highest number of fruit plant ${ }^{-1}(14.0)$ was identified using biochar, compared with control.

Table 6. Effect of compost, biochar, fruit and vegetable waste (F and V waste) and Bacillus subtilis SMBL 1 on number of fruit plant ${ }^{-1}$ and fruit fresh and dry biomass of okra.

\begin{tabular}{|c|c|c|c|c|c|c|}
\hline \multirow{2}{*}{ Treatments } & \multicolumn{2}{|c|}{ Number of Fruit Plant -1} & \multicolumn{2}{|c|}{$\begin{array}{l}\text { Fruit Fresh Biomass } \\
\qquad\left(\mathrm{g} \mathrm{plant}^{-1}\right)\end{array}$} & \multicolumn{2}{|c|}{$\begin{array}{l}\text { Fruit Dry Biomass } \\
\qquad\left(\mathrm{g} \text { plant }^{-1}\right)\end{array}$} \\
\hline & Un-Inoculated & Inoculated & Un-Inoculated & Inoculated & Un-Inoculated & Inoculated \\
\hline Control & $8.0 \mathrm{~g}$ & $9.0 \mathrm{fg}$ & $59.3 \mathrm{~g}$ & $72.8 \mathrm{e}$ & $11.0 \mathrm{~g}$ & $12.0 \mathrm{fg}$ \\
\hline Compost & $10.0 \mathrm{ef}$ & $11.0 \mathrm{de}$ & $67.5 \mathrm{f}$ & $82.0 \mathrm{c}$ & $13.0 \mathrm{ef}$ & $15.0 \mathrm{~cd}$ \\
\hline Biochar & $14.0 \mathrm{c}$ & $18.0 \mathrm{a}$ & $78.5 \mathrm{~d}$ & $105.3 \mathrm{a}$ & $16.0 \mathrm{bc}$ & $18.50 \mathrm{a}$ \\
\hline $\mathrm{F}$ and $\mathrm{V}$ waste & $12.0 \mathrm{~d}$ & $16.0 \mathrm{~b}$ & $74.5 \mathrm{e}$ & $96.3 \mathrm{~b}$ & $14.0 \mathrm{de}$ & $17.0 \mathrm{~b}$ \\
\hline $\operatorname{LSD}(p \leq 0.05)$ & \multicolumn{2}{|c|}{0.2261} & \multicolumn{2}{|c|}{0.0461} & \multicolumn{2}{|c|}{0.1383} \\
\hline
\end{tabular}

Means sharing different letters are statistically significant in respect to each other at $5 \%$ level of probability $(n=4)$.

Data regarding the effect of PGPR with organic amendments on fruit fresh and dry biomass and fruit length and diameter, revealed that the biomass of fruit was improved due to these amendments (Tables 6 and 7). The highest increases in fruit fresh and dry biomass, fruit length and diameter were observed in SMBL 1 + biochar, that is, 44.7, 54.2, 40.4 and $27.4 \%$, respectively. Fruit and vegetable waste and compost with the SMBL 1 strain also showed significant results, while, in sole application of organic amendments, biochar showed prominent results compared with control.

Table 7. Effect of compost, biochar, fruit and vegetable waste ( $\mathrm{F}$ and $\mathrm{V}$ waste) and Bacillus subtilis SMBL 1 on fruit length and diameter in okra.

\begin{tabular}{ccccc}
\hline \multirow{2}{*}{ Treatments } & \multicolumn{2}{c}{ Fruit Length $(\mathbf{c m})$} & \multicolumn{2}{c}{ Average Fruit Diameter (cm) } \\
\cline { 2 - 5 } & Un-Inoculated & Inoculated & Un-Inoculated & Inoculated \\
\hline Control & $8.36 \mathrm{~g}$ & $10.8 \mathrm{e}$ & $1.43 \mathrm{f}$ & $1.55 \mathrm{ef}$ \\
Compost & $9.65 \mathrm{f}$ & $12.6 \mathrm{c}$ & $1.60 \mathrm{de}$ & $1.70 \mathrm{~b}-\mathrm{d}$ \\
Biochar & $11.4 \mathrm{~d}$ & $15.1 \mathrm{a}$ & $1.75 \mathrm{dc}$ & $1.98 \mathrm{a}$ \\
F and V waste & $10.8 \mathrm{e}$ & $14.0 \mathrm{~b}$ & $1.68 \mathrm{c}-\mathrm{e}$ & $1.83 \mathrm{~b}$ \\
\hline LSD $(p \leq 0.05)$ & \multicolumn{3}{c}{0.1390} \\
\hline Means sharing different letters are statistically significant in respect to each other at 5\% level of probability $(n=4)$.
\end{tabular}

\subsection{Fe and $\mathrm{Zn}$ in Shoot}

The results showed that the inoculation of seed with the SMBL 1 strain in the presence of biochar, fruit and vegetable waste, and compost significantly improved Fe and $\mathrm{Zn}$ contents in shoot of okra (Figure 2). Biochar + SMBL 1 improved Fe and Zn contents up to $37.1 \%$ and $35.6 \%$, respectively, while, in the absence of the strain SMBL 1, organic amendments also showed better results than control. 

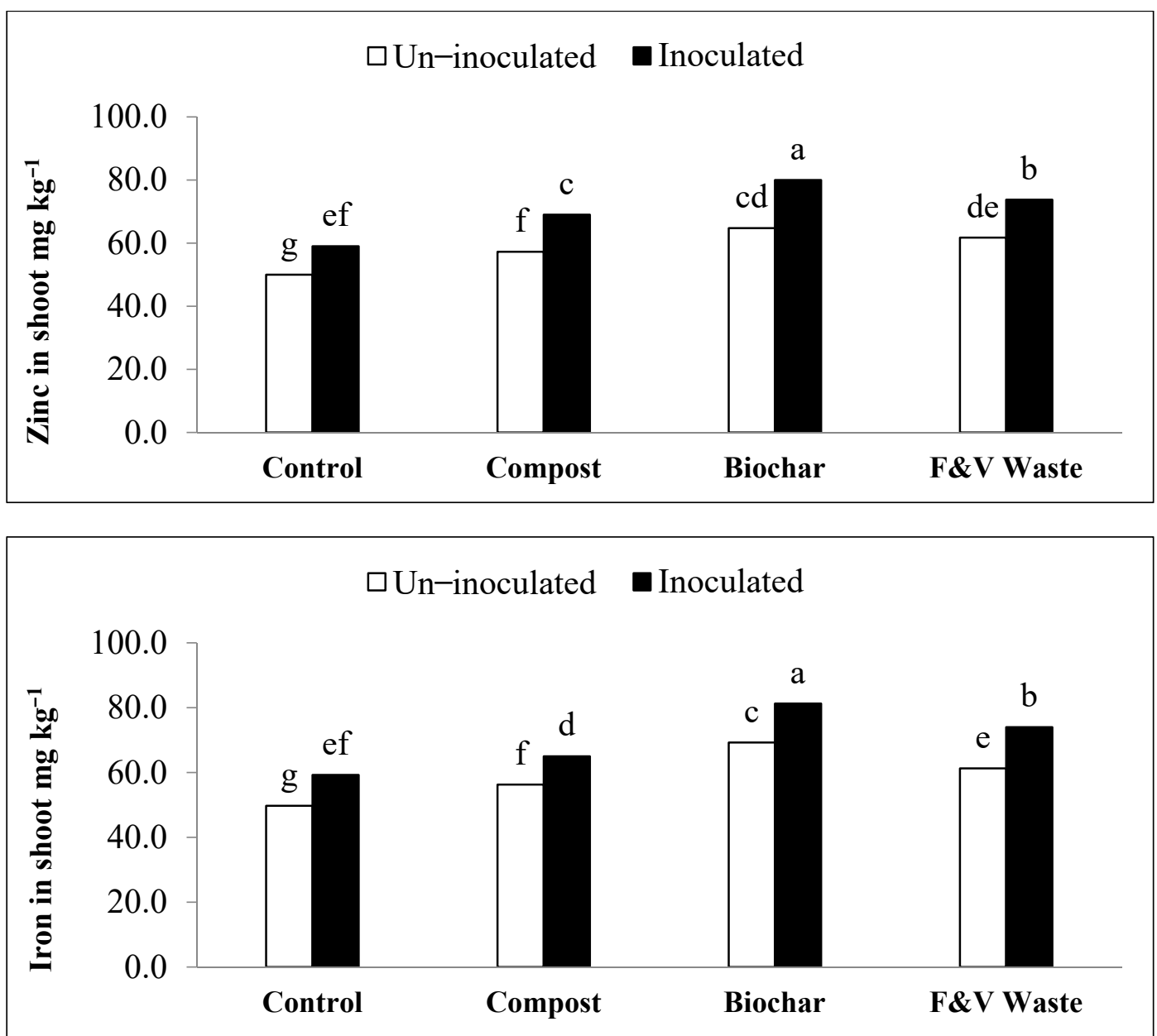

Figure 2. Effect of biochar, fruit and vegetable waste, compost and Bacillus subtilis SMBL 1 on Fe and Zn contents in okra with un-inoculated treatment set (Control = no bacterial inoculation) and inoculated treatment set (Control = SMBL 1). Different letters indicate significant differences according to least significant difference test at $(p \leq 0.05)$.

\subsection{Physiological Parameters of Okra}

Inoculation with the SMBL 1 strain in the presence of organic amendments significantly improved the RWC (relative water content) and chlorophyll ' $a$ ' and ' $b$ ' contents (Figure 3). Compared with control, biochar and inoculation of SMBL 1 strain application showed the highest increase in RWC and chlorophyll ' $a$ ' and ' $b$ ', that is, 4.3, 50 and $53.3 \%$, respectively. The sole use of organic amendments physiological attributes of okra showed better results than control. 

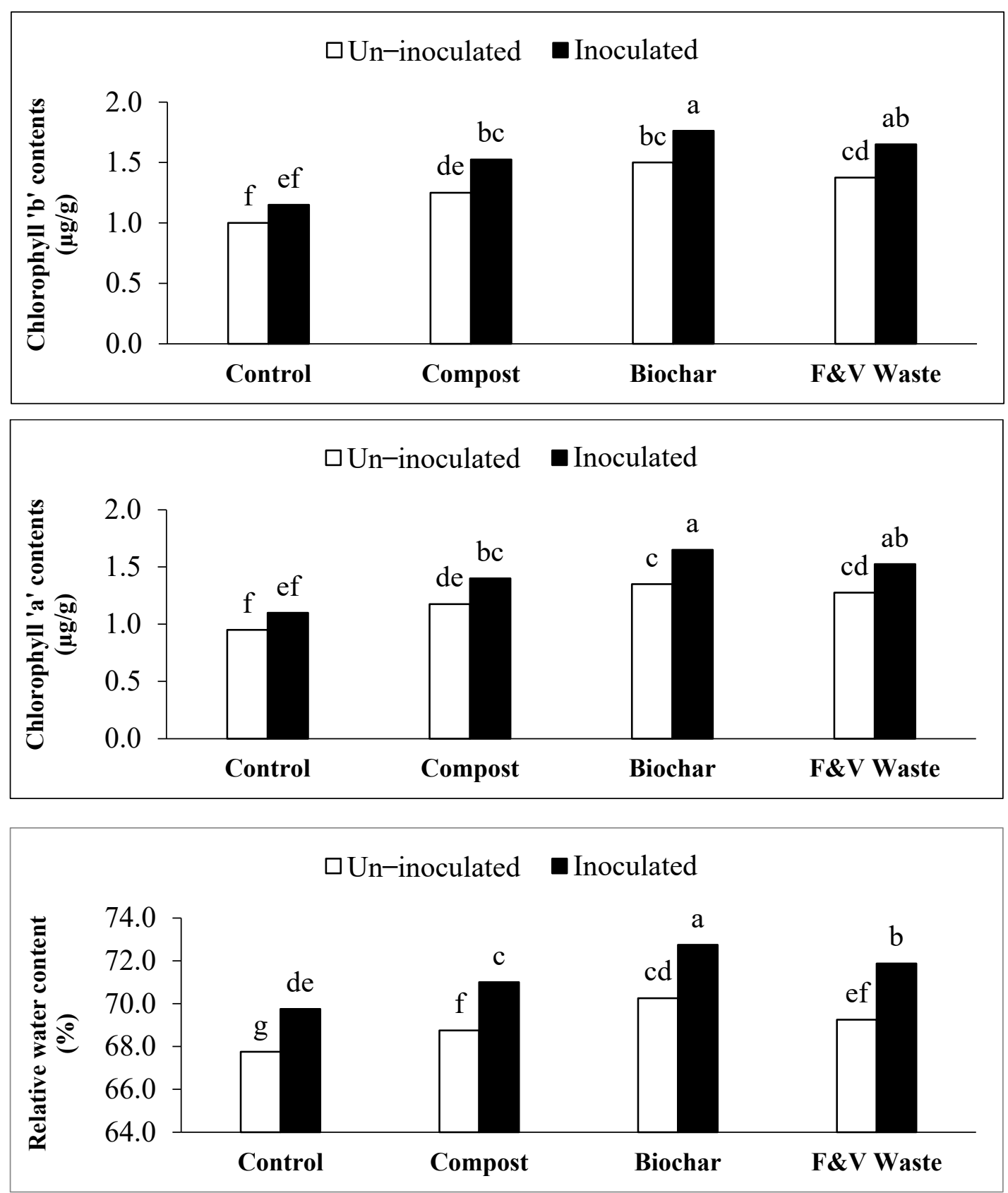

Figure 3. Effect of biochar, fruit and vegetable waste, compost and Bacillus subtilis SMBL 1 on relative water content, chlorophyll ' $a$ ' and ' $b$ ' in okra with un-inoculated treatment set (Control = no bacterial inoculation) and inoculated treatment set (Control = SMBL 1 only). Different letters indicate significant differences according to least significant difference test at $(p \leq 0.05)$.

\subsection{Microbial Population in Soil}

As shown in Figure 4, the inoculation of the SMBL 1 strain significantly improved the effect of each organic amendment applied individually or in combined form on soil bacterial population or CFU. In general, the SMBL 1 strain showed the capability to increase the effectiveness of soil organic amendments (i.e., soil water-holding capacity and decomposition ability of soil). This strain showed maximum results with biochar that was $30.8 \%$, followed by fruit and vegetable waste $(20.3 \%)$ and compost $(9.8 \%)$ treatments, compared to control, while, in the sole application of organic amendments, bacterial populations also improved (but not as much as with inoculated treatments) compared with control. 


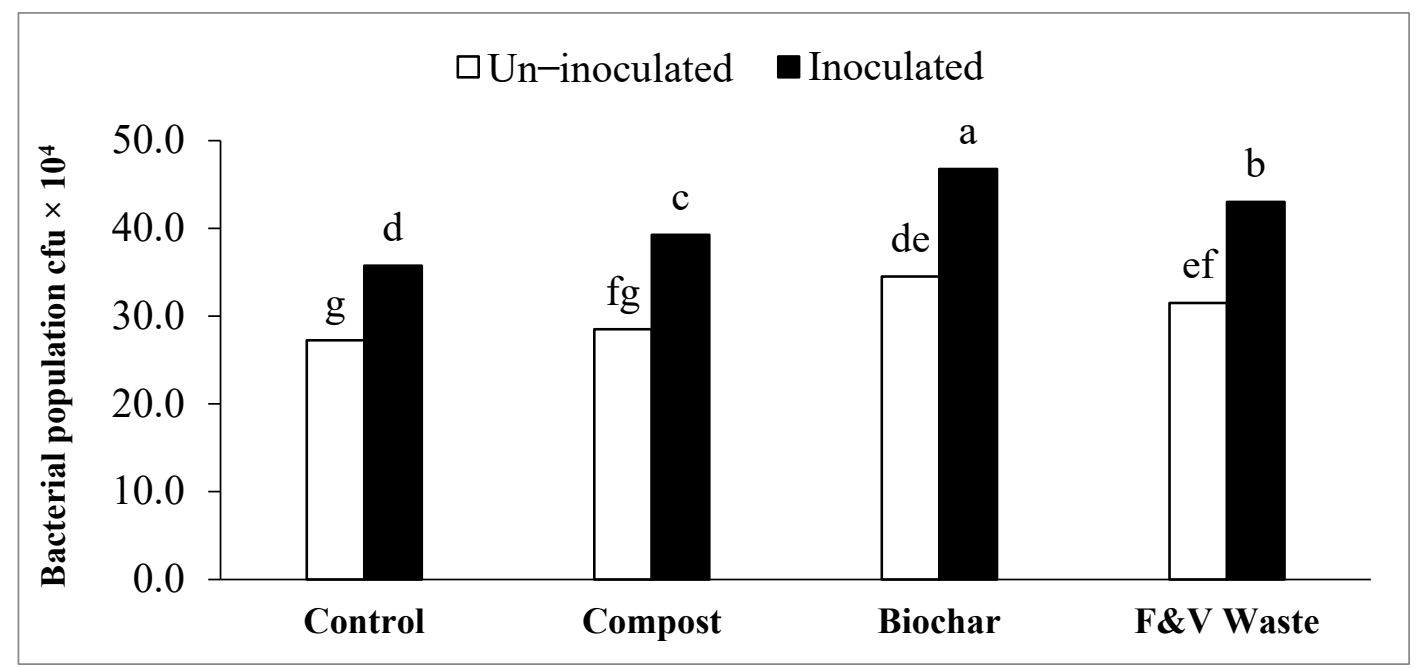

Figure 4. Effect of biochar, fruit and vegetable waste, compost and Bacillus subtilis SMBL 1 on bacterial CFU of soil with un-inoculated treatment set (Control = no bacterial inoculation) and inoculated treatment set (Control = SMBL 1 only). Different letters indicate significant differences according to least significant difference test at $(p \leq 0.05)$.

\section{Discussion}

Different kinds of bacterial species are present in rhizospheric soil that colonize the roots of plants [48] and have various traits that are useful for sustainable agricultural production. PGPR are an important group of bacteria that increase the growth of plants by improving nutrient availability [49], resulting in better crop production. Thus, PGPR have potential for utilization as biofertilizers to overcome reduced nutrient uptake issues in plants [50]. The results of this study clearly confirm that the use of PGPR considerably improved growth and yield parameters in okra. Particularly, inoculation of seed with PGPR significantly increases the physiological, yield and growth parameters. Our findings are in line with the those in the literature, as it was found that the inoculation of the Azotobacter, Pseudomonas and Azospirillum strains in different crops also expressed a similar improvement in plant growth and yield [51].

Our results demonstrated that the application of compost, biochar, fruit and vegetable waste and Bacillus subtilis (SMBL 1) inoculation led to a significant increase in the chlorophyll ' $a$ ' and ' $b$ ' contents and RWC of okra plant. This increase might be due to higher root lengths and biomass, which enhance the uptake of water from soil and RWC of plant. The results of our study are in agreement with the findings obtained by Ahmad et al. [52], who reported that co-inoculation of Rhizobia and PGPR can enhance root length and cause an increase in the uptake of water from deeper soil regions. Ullah et al. [53], Mumtaz et al. [54] and Fatawi et al. [55] argued that the use of rhizobacteria and organic amendments (compost and biochar) increases the root surface area, root length and stomatal conductance, that, in turn, improve the absorption of water from deeper regions and ultimately result in an increase in RWC. Co-inoculation of PGPR and Rhizobium possessing ACC-deaminase activity promotes roots elongation that aids the plant to absorb more water from soil [49]. The enhancement of chlorophyll contents in the present study might be due to the improvement in plant nutrient uptake, especially $\mathrm{N}, \mathrm{Fe}$ and $\mathrm{Mg}$ (core components of chlorophyll molecules) by microbial inoculation, similar to the findings reported by Adesemoye and Kloepper [56]. Therefore, the improvement in chlorophyll contents expedites photosynthesis and the production of photosynthates, which is responsible for the increase in crop yield. The results of the present study clearly confirm that the application of organic amendments (biochar, compost, and fruit and vegetable waste) and Bacillus subtilis (SMBL 1) considerably enhanced plant height, shoot dry and fresh biomass and root length of okra. Parewa and Yadav [57] and Fatawi et al. [55] demonstrated the role of bacterial species such as Arthrobacter, Azotobacter, Bacillus, Azospirillum, Enterobacter, Pseu- 
domonas and Burkholderia integrated with organic amendments to increase plant growth and yield attributes. Adesemoye and Ugoji [58] also observed similar results by evaluating the ability of Pseudomonas sp. to improve the growth of plants using three different crops (okra, tomato, African spinach). They found that the inoculation of Pseudomonas specie is a promising strategy that can be used to improve crop growth. The microorganisms present in soil usually develop favorable conditions for suitable vegetative growth; for instance, they enhance nutrient uptake in plants and enhance plant height and root length of plant. Microorganisms used in biofertilizers play an important role in organic matter decomposition and the application of organic amendments with PGPR play a significant role in their decomposition and associate with soil health plant growth and nutrient cycling [59]. PGPR inoculation considerably increases the length of root, and dry and fresh biomass of root; similar findings were also recorded by Richardson [60] in terms of improvements in surface area and root biomass. The higher microbial population in the soil of SMBL1inoculated plants was also found, as the microbial activity in soil is a function of root exudation in the rhizosphere and the availability of other $\mathrm{C}$ and nutrient sources, which have the ability to alter the soil biological and physiochemical properties; similar facts were also advocated by Nardi et al. [61]. Furthermore, these may improve the root surface area, which can hold more soil and alter the nutrient status and biological activity in the rhizosphere [62].

The inoculation of SMBL 1 and use of organic amendments (compost, biochar, and fruit and vegetable waste) considerably increased the uptake of nutrients in okra plant, resulting in improved crop yield. The results of our research are in agreement with Biari et al.'s [63], who described that the Azospirillum strain considerably improved the uptake of nutrients by plants such as $\mathrm{N}, \mathrm{P}, \mathrm{K}, \mathrm{Zn}, \mathrm{Fe}, \mathrm{Cu}$ and $\mathrm{Mn}$. The rise in the uptake of micro- and macro-nutrients capability of plants is due to the application of organic amendments and inoculation with PGPR that result in the formation and improvement of lateral roots and improve the root biomass. Similar findings were also presented in Ahmad et al. [48,52] and Nadeem et al. [64], who reported that the application of PGPR increased the root surface area through the propagation of roots and improved the nutrient availability. Organic amendments are rich in C, N, P, K in organic forms, while PGPR have ability to decompose the organic amendments and convert them into their respective inorganic/plant-available forms [65]. Bouain et al. [66] described that the micro- and macro-nutrients absorption by plants from the soil depends upon the release of organic acids such as lactic acid, citric acid, gluconic acid and 5-keto gluconic acid by rhizosphere microorganisms; thus, by lowering the microsite $\mathrm{pH}$, these microorganisms increase the amount of nutrients available to the roots of the plant [67]. Similar reasons were also provided by Estrada et al. [68], Abaid-Ullah et al. [69] and Zhang and Kong [70], who explained that rhizo-bacteria have the capability of releasing acids such as oxalic, malic, lactic and gluconic acids for $\mathrm{K}, \mathrm{Zn}, \mathrm{Fe}$ and (PO4) ${ }^{-3}$ solubilization. Furthermore, the use of organic amendments improves the growth and yield of the plant by increasing the fertility status of soil. The yield improvements by inoculation might be linked with the increase in nutrient uptake through the increase in root biomass, enhancement of photosynthesis, growth-promoting substances by microorganisms and provision of favorable conditions by organic amendments [28].

\section{Conclusions}

The inoculation of Bacillus subtilis (SMBL 1) and use of organic amendments (biochar, fruit and vegetable waste, and compost) improved the soil properties and okra growth when applied individually and in combination with each other. Promising results were obtained by the integrated application of SMBL 1 and biochar, which caused an increase in RWC (4.3\%), fruit N contents (33\%), fruit P contents (52.7\%), fruit K contents $(25.6 \%)$, shoot iron contents $(37.1 \%)$, shoot zinc contents $(35.6 \%)$, rhizospheric microbial population $(30.8 \%)$ and yield $(44.7 \%)$ of okra, compared with control. Considering the promising results obtained by the integration of SMBL 1 and biochar, it can be concluded that the current approach has the potential to be developed into a sustainable technology for okra production after extensive evaluation in the field is carried out. The development of 
biofertilizer for the sustainable production of vegetables is the need of the hour, not only to restore soil health but also to attain food security in Pakistan. Moreover, the entrapped nutrients in the organic amendments can be readily solubilized by SMBL 1, reduce chemical fertilizer application and improve the organic matter status and microbial diversity in soil for sustainable agricultural production.

Author Contributions: Conceptualization, A.H., H.A. and X.W.; methodology, M.A., A.M. and A.D.; software, A.M. and A.D.; validation, A.H., M.R., M.L., M.A., M.U.J. and A.M.; writing-original draft preparation, A.H., H.A. and X.W.; writing-review and editing, I.K., M.U.J., A.M., X.W., M.A. and A.D. All authors have read and agreed to the published version of the manuscript.

Funding: This research received no external funding.

Institutional Review Board Statement: Not applicable.

Informed Consent Statement: Not applicable.

Data Availability Statement: Strain identification and accession number data is available at https: / / www.ncbi.nlm.nih.gov/nuccore/MN007187.1/ assessed online (5 September 2021).

Acknowledgments: The authors are thankful to the Department of Soil Science, The Islamia University of Bahawalpur, Pakistan, for the provision of research permission and facilities at Soil Microbiology and Biotechnology Laboratory, Department of Soil Science, The Islamia University of Bahawalpur.

Conflicts of Interest: There was no financial or relational conflict of interest during the preparation and submission of this work.

\section{References}

1. Kashif, S.; Yaseen, M.; Arshad, M.U.; Ayub, M. Response of okra (Hibiscus esculentus L.) to soil given encapsulated calcium carbide. Pak. J. Bot. 2008, 4, 175-181.

2. Bawa, S.H.; Badrie, N. Nutrient profile, bioactive components, and functional properties of okra (Abelmoschus esculentus (L.) Moench). In Fruit, Vegetables, and Herbs: Bioactive Foods in Health Promotion; Watson, R.R., Preedy, V.R., Eds.; Academic Press: London, UK, 2016; pp. 365-409.

3. Norman, J.C. Tropical Vegetable Crops; Arthur, H., Ed.; Stockwell Limited: Ilfracombe, UK, 1992; pp. 97-103.

4. MINFSR. Fruits Vegetables and Condiment Statistics of Pakistan; Ministry of National Food Security and Research Islamabad: Islamabad, Pakistan, 2019; pp. 11-20.

5. Ali, H.A.; Randhawa, S.A.; Yousaf, M.U. Quantitative and qualitative traits of sunflower (Helianthus annus L.) as influenced by planting dates and nitrogen application. Int. J. Agric. Biol. 2004, 6, 4102.

6. Noorhosseini, S.A.; Damalas, C.A. Environmental Impact of Peanut (Arachis hypogaea L.) Production under Different Levels of Nitrogen Fertilization. Agriculture 2018, 8, 104. [CrossRef]

7. Nie, S.; Zhao, L.; Lei, X.; Sarfraz, R.; Xing, S. Dissolved organic nitrogen distribution in differently fertilized paddy soil profiles: Implications for its potential loss. Agric. Ecosyst. Environ. 2018, 262, 58-64. [CrossRef]

8. Oldfield, E.E.; Bradford, M.A.; Wood, S.A. Global meta-analysis of the relationship between soil organic matter and crop yields. Soil 2019, 5, 15-32. [CrossRef]

9. Peltre, C.; Gregorich, E.G.; Bruun, S.; Jensen, L.S.; Magid, J. Repeated application of organic waste affects soil organic matter composition: Evidence from thermal analysis, FTIR-PAS, amino sugars and lignin biomarkers. Soil Biol. Biochem. 2017, 104, 117-127. [CrossRef]

10. Ramesh, P. Organic Farming Research in M.P. In Organic Farming in Rain Fed Agriculture; Central Institute from Dry land Agriculture: Hyderabad, India, 2008; pp. 13-17.

11. Bonanomi, G.; De Filippis, F.; Zotti, M.; Idbella, M.; Cesarano, G.; Al-Rowaily, S.; Abd-ElGawad, A. Repeated applications of organic amendments promote beneficial microbiota, improve soil fertility and increase crop yield. Appl. Soil Ecol. 2020, 156, 103714. [CrossRef]

12. Lone, A.H.; Najar, G.R.; Ganie, M.A.; Sofi, J.A.; Ali, T. Biochar for Sustainable Soil Health: A Review of Prospects and Concerns. Pedosphere 2015, 25, 639-653. [CrossRef]

13. Mukherjee, A.; Lal, R. Biochar Impacts on Soil Physical Properties and Greenhouse Gas Emissions. Agronomy 2013, 3, 313-339. [CrossRef]

14. Tang, J.; Zhu, W.; Kookana, R.; Katayama, A. Characteristics of biochar and its application in remediation of contaminated soil. J. Biosci. Bioeng. 2013, 116, 653-659. [CrossRef] 
15. Usman, A.R.; Al-Wabel, M.I.; Abdulaziz, A.H.; Mahmoud, W.A.; El-Naggarah, A.H.; Ahmadm, M.; Abdulelah, A.F.; Abdulrasoul, A.O. Conocarpus biochar induces changes in soil nutrient availability and tomato growth under saline irrigation. Pedosphere 2016, 26, 27-38. [CrossRef]

16. Sänger, A.; Reibe, K.; Mumme, J.; Kaupenjohann, M.; Ellmer, F.; Roß, C.-L.; Meyer-Aurich, A. Biochar application to sandy soil: Effects of different biochars and N fertilization on crop yields in a 3-year field experiment. Arch. Agron. Soil Sci. 2017, 63, 213-229. [CrossRef]

17. Naeem, M.A.; Khalid, M.; Aon, M.; Abbas, G.; Tahir, M.; Amjad, M.; Murtaza, B.; Yang, A.; Akhtar, S.S. Effect of wheat and rice straw biochar produced at different temperatures on maize growth and nutrient dynamics of a calcareous soil. Arch. Agron. Soil Sci. 2017, 63, 2048-2061. [CrossRef]

18. Ye, J.; Zhang, R.; Nielsen, S.; Joseph, S.D.; Huang, D.; Thomas, T. A Combination of Biochar-Mineral Complexes and Compost Improves Soil Bacterial Processes, Soil Quality, and Plant Properties. Front. Microbiol. 2016, 7, 372. [CrossRef]

19. Ma, N.; Zhang, L.; Zhang, Y.; Yang, L.; Yu, C.; Yin, G.; Doane, T.A.; Wu, Z.; Zhu, P.; Ma, X. Biochar Improves Soil Aggregate Stability and Water Availability in a Mollisol after Three Years of Field Application. PLoS ONE 2016, 11, e0154091. [CrossRef]

20. Atkinson, C.J. How good is the evidence that soil-applied biochar improves water-holding capacity? Soil Use Manag. 2018, 34, 177-186. [CrossRef]

21. Aranyos, J.T.; Tomócsik, A.; Makádi, M.; Mészáros, J.; Blaskó, L. Changes in physical properties of sandy soil after long-term compost treatment. Int. Agrophys. 2016, 30, 269-274. [CrossRef]

22. Tafaghodinia, B.; Kamalpour, M. Compost Tea; Sepehr, Ed.; Persian: Tehran, Iran, 2008; p. 75.

23. Moharana, P.C.; Meena, M.D.; Biswas, D.R. Role of phosphate-solubilizing microbes in the enhancement of fertilizer value of rock phosphate through composting technology. In Role of Rhizospheric Microbes in Soil: Nutrient Management and Crop Improvement; Meena, V.S., Ed.; Springer Nature Singapore Pte Ltd.: Singapore, 2018.

24. Batista, E.M.C.C.; Shultz, J.; Matos, T.T.S.; Fornari, M.R.; Ferreira, T.M.; Szpoganicz, B.; de Freitas, R.; Mangrich, A.S. Effect of surface and porosity of biochar on water holding capacity aiming indirectly at preservation of the Amazon biome. Sci. Rep. 2018, 8, 1-9. [CrossRef]

25. Mus, F.; Crook, M.B.; Garcia, K.; Costas, A.G.; Geddes, B.A.; Kouri, E.D.; Paramasivan, P.; Ryu, M.-H.; Oldroyd, G.E.; Poole, P.S.; et al. Symbiotic Nitrogen Fixation and the Challenges to Its Extension to Nonlegumes. Appl. Environ. Microbiol. 2016, 82, 3698-3710. [CrossRef]

26. Jian, S.; Li, J.; Chen, J.; Wang, G.; Mayes, M.A.; Dzantor, K.E.; Hui, D.; Luo, Y. Soil extracellular enzyme activities, soil carbon and nitrogen storage under nitrogen fertilization: A meta-analysis. Soil Biol. Biochem. 2016, 101, 32-43. [CrossRef]

27. Ahmad, M.; Adil, Z.; Hussain, A.; Mumtaz, M.Z.; Nafees, M.; Ahmad, I.; Jamil, M. Potential of phosphate solubilizing Bacillus strains for improving growth and nutrient uptake in mungbean and maize crops. Pak. J. Agric. Sci. 2019, 56, $283-289$.

28. Kumar, A.; Patel, J.S.; Meena, V.S.; Ramteke, P.W. Plant growth-promoting rhizobacteria: Strategies to improve abiotic stresses under sustainable agriculture. J. Plant Nutr. 2019, 42, 1402-1415. [CrossRef]

29. Mumtaz, M.Z.; Ahmad, M.; Jamil, M.; Hussain, T. Zinc solubilizing Bacillus spp. potential candidates for biofortification in maize. Microbiol. Res. 2017, 202, 51-60. [CrossRef]

30. Hale, L.; Luth, M.; Crowley, D. Biochar characteristics relate to its utility as an alternative soil inoculum carrier to peat and vermiculite. Soil Biol. Biochem. 2015, 81, 228-235. [CrossRef]

31. Nadeem, S.M.; Imran, M.; Naveed, M.; Khan, M.Y.; Ahmad, M.; Zahir, Z.A.; Crowley, D.E. Synergistic use of biochar, compost and plant growth-promoting rhizobacteria for enhancing cucumber growth under water deficit conditions. J. Sci. Food Agric. 2017, 97, 5139-5145. [CrossRef] [PubMed]

32. Mahuku, G.S. A simple extraction method suitable for PCR-based analysis of plant, fungal, and bacterial DNA. Plant Mol. Biol. Rep. 2004, 22, 71-81. [CrossRef]

33. Thompson, J.D.; Gibson, T.J.; Plewniak, F.; Jeanmougin, F.; Higgins, D.G. The CLUSTAL X windows interface: Flexible strategies for multiple sequence alignment aided by quality analysis tools. Nucleic Acids Res. 1997, 25, 4876-4882. [CrossRef]

34. Perrière, G.; Gouy, M. WWW-query: An on-line retrieval system for biological sequence banks. Biochimie 1996, 78, 364-369. [CrossRef]

35. Ryan, J.; Estefan, G.; Rashid, A. Soil and Plant Analysis Laboratory Manual, 2nd ed.; International Center for Agricultural Research in the Dry Areas (ICARDA): Aleppo, Syria, 2001; p. 172.

36. Yeomans, J.C.; Bremner, J.M. A rapid and precise method for routine determination of organic carbon in soil. Commun. Soil Sci. Plant Anal. 1988, 19, 1467-1476. [CrossRef]

37. Jackson, M.L. Soil Chemical Analysis; Prentice Hall Pvt, Ltd.: New Delhi, India, 1973.

38. McGill, W.B.; Figueiredo, C.T. Total nitrogen: Chapter 22. In Soil Sampling and Methods of Analysis; Carter, M.R., Ed.; Lewis Publishers: Boca Raton, FL, USA, 1993.

39. Dar, A.; Zahir, Z.A.; Asghar, H.N.; Ahmad, R. Preliminary screening of rhizobacteria for biocontrol of little seed canary grass (Phalaris minor Retz.) and wild oat (Avena fatua L.) in wheat. Can. J. Microbiol. 2020, 66, 368-376. [CrossRef] [PubMed]

40. Khalid, A.; Arshad, M.; Zahir, Z. Screening plant growth-promoting rhizobacteria for improving growth and yield of wheat. $J$. Appl. Microbiol. 2004, 96, 473-480. [CrossRef]

41. Russel, A.D.; Hugo, W.B.; Ayliffo, G.A.J. Principles and Practices of Disinfection, Preservation and Sterilization; Black Wall Scientific: London, UK, 1982. 
42. Ayers, R.S.; Westcot, D.W. Water Quality for Agriculture; FAO Irrigation and Drainage Papers 29 (Rev.1); FAO: Rome, Italy, 1985.

43. Mayak, S.; Tirosh, T.; Glick, B.R. Plant growth-promoting bacteria that confer resistance to water stress in tomatoes and peppers. Plant Sci. 2004, 166, 525-530. [CrossRef]

44. Arnon, D.I. Copper enzymes in isolated chloroplasts, polyphenoxidase in Beta vulgaris. Plant Physiol. 1949, 24, 1-15. [CrossRef]

45. Wolf, B. The comprehensive system of leaf analysis and its use for diagnosing crop nutrient status. Commun. Soil Sci. Plant Anal. 1982, 13, 1035-1059. [CrossRef]

46. Alexander, M. Most probable number method for microbial populations. In Methods of Soil Analysis, Part 2; Page, A.L., Miller, R.H., Keeney, D.R., Eds.; ASA and SSA: Madison, WI, USA, 1982; pp. 815-820.

47. Steel, P. The nature of procrastination: A meta-analytic and theoretical review of quintessential self-regulatory failure. Psychol. Bull. 2007, 133, 65-94. [CrossRef]

48. Ahamd, M.; Zahir, Z.A.; Nadeem, S.M.; Nazli, F.; Jamil, M.; Jamshaid, M.U. Physiological response of mung bean to Rhizobium and Pseudomonas based biofertilizers under salinity stress. Pak. J. Agric. Sci. 2014, 51, 555-562.

49. Ahmad, M.; Zahir, Z.A.; Nadeem, S.M.; Nazli, F.; Jamil, M.; Khalid, M. Field evaluation of Rhizobium and Pseudomonas strains to improve growth, nodulation and yield of mung bean under salt-affected conditions. Soil Environ. 2013, 32, $158-166$.

50. Meunchang, S.; Panichsakpatana, S.; Weaver, R.W. Co-composting of filter cake and bagasse; by-products from a sugar mill. Bioresour. Technol. 2005, 96, 437-442. [CrossRef] [PubMed]

51. Shaukat, K.; Affrasayab, S.; Hasnain, S. Growth responses of Triticwn aestivum to plant growth promoting rhizobacteria used as a bio fertilizer. Res. J. Microbiol. 2010, 5, 1022-1030.

52. Ahmad, M.; Zahir, Z.A.; Asghar, H.N.; Asghar, M. Inducing salt tolerance in mung bean through coinoculation with rhizobia and plant-growth-promoting rhizobacteria containing 1-aminocyclopropane-1-carboxylate deaminase. Can. J. Microbiol. 2011, 57, 578-589. [CrossRef] [PubMed]

53. Ullah, N.; Ditta, A.; Imtiaz, M.; Li, X.; Jan, A.U.; Mehmood, S.; Rizwan, M.S. Appraisal for organic amendments and plant growth-promoting rhizobacteria to enhance crop productivity under drought stress: A review. J. Agron. Crop. Sci. 2021, 207, 783-802. [CrossRef]

54. Mumtaz, M.Z.; Ahmad, M.; Jamil, M.; Asad, S.A.; Hafeez, F. Bacillus strains as potential alternate for zinc biofortification of maize grains. Int. J. Agric. Biol. 2018, 20, 1779-1786.

55. Fatawi, A.; Pujiasmanto, B.; Zaki, M.K.; Noda, K. Application of organic amendments and PGPR on Salibu Rice yield for drought adaptation. In IOP Conference Series: Earth and Environmental Science; IOP Publishing: Bristol, UK, 2021; Volume 824, p. 012079.

56. Adesemoye, A.O.; Kloepper, J.W. Plant-microbes interactions in enhanced fertilizer-use efficiency. Appl. Microbiol. Biotechnol. 2009, 85, 1-12. [CrossRef] [PubMed]

57. Parewa, H.P.; Yadav, J. Response of fertility levels, FYM and bioinoculants on yield attributes, yield and quality of wheat. Agri. Sustain. Dev. 2014, 2, 5-10.

58. Adesemoye, A.O.; Ugoji, E.O. Evaluating Pseudomonas aeruginosa as plant growth promoting rhizobacteria (PGPR) in West Africa Arch. Phytopathol. Plant Prot. 2006, 42, 188-200. [CrossRef]

59. Han, X.-M.; Wang, R.-Q.; Liu, J.; Wang, M.-C.; Zhou, J.; Guo, W.-H. Effects of vegetation type on soil microbial community structure and catabolic diversity assessed by polyphasic methods in North China. J. Environ. Sci. 2007, 19, 1228-1234. [CrossRef]

60. Richardson, A.E. Prospects for using soil microorganisms to improve the acquisition of phosphorus by plants. Funct. Plant Biol. 2001, 28, 897-906. [CrossRef]

61. Nardi, S.; Concheri, G.; Pizzeghello, D.; Sturaro, A.; Rella, R.; Parvoli, G. Soil organic matter mobilization by root exudates. Chemosphere 2000, 41, 653-658. [CrossRef]

62. Iqbal, M.A.; Khalid, M.; Shahzad, S.M.; Ahmad, M.; Soleman, N.; Akhtar, N. Integrated use of Rhizobium leguminosarum, Plant Growth Promoting Rhizobacteria and Enriched Compost for Improving Growth, Nodulation and Yield of Lentil (Lens culinaris Medik.). Chil. J. Agric. Res. 2012, 72, 104-110. [CrossRef]

63. Biari, A.; Gholami, A.; Rahmani, H. Growth Promotion and Enhanced Nutrient Uptake of Maize (Zea mays L.) by Application of Plant Growth Promoting Rhizobacteria in Arid Region of Iran. J. Biol. Sci. 2008, 8, 1015-1020. [CrossRef]

64. Nadeem, S.; Hamed, M.; Asghar, M.J.; Abbas, G.; Saeed, N.A. Screening of mungbean (Vigna radiata (L.) Wilczek) genotypes against sucking insect pests under natural field conditions. Pak. J. Zool. 2014, 46, 863-866.

65. Tarin, M.W.K.; Fan, L.; Tayyab, M.; Sarfraz, R.; He, T.; Rong, J.; Chen, L.; Zheng, Y. Effects of bamboo biochar amendment on the growth and physiological characteristics of Fokienia hodginsii. Appl. Ecol. Environ. Res. 2018, 16, 8055-8074. [CrossRef]

66. Bouain, N.; Shahzad, Z.; Rouached, A.; Khan, G.A.; Berthomieu, P.; Abdelly, C.; Poirier, Y.; Rouached, H. Phosphate and zinc transport and signalling in plants: Toward a better understanding of their homeostasis interaction. J. Exp. Bot. 2014, 65, 5725-5741. [CrossRef] [PubMed]

67. Tayyab, M.; Islam, W.; Arafat, Y.; Pang, Z.; Zhang, C.; Lin, Y.; Waqas, M.; Lin, S.; Lin, W.; Zhang, H. Effect of Sugarcane Straw and Goat Manure on Soil Nutrient Transformation and Bacterial Communities. Sustainability 2018, 10, 2361. [CrossRef]

68. Estrada, G.A.; Baldani, V.L.D.; de Oliveira, D.M.; Urquiaga, S.; Baldani, J.I. Selection of phosphate-solubilizing diazotrophic Herbaspirillum and Burkholderia strains and their effect on rice crop yield and nutrient uptake. Plant Soil 2013, 369, 115-129. [CrossRef] 
69. Abaid-Ullah, M.; Hassan, M.N.; Jamil, M.; Brader, G.; Shah, M.K.N.; Sessitsch, A. Plant growth promoting rhizobacteria: An alternate way to improve yield and quality of wheat (Triticum aestivum). Int. J. Agric. Biol. 2015, 17, 51-60.

70. Zhang, C.; Kong, F. Isolation and identification of potassium-solubilizing bacteria from tobacco rhizospheric soil and their effect on tobacco plants. Appl. Soil Ecol. 2014, 82, 18-25. [CrossRef] 